\title{
Logging and Rafting Square Timber in Ontario and Québec for Shipment to Great Britain circa 1870 to 1908
}

collection of lantern slides (transparent glass plates) illustrating logging and rafting of square timber in Ontario was used occasionally as a teaching resource at the Faculty of Forestry, University of Toronto. Since the Faculty was formed in 1907, these lantern slides have been passed on from professor to professor for safekeeping.

Crosscut saws were first used for felling trees in Ontario in the 1870s (note the flat ends on most of the logs illustrated), and 1908 was the year the last timber raft floated down the Ottawa River to the Port de Québec. These lantern slides are typical of 1870-1908 logging and rafting square timber in the Ottawa and Saint Lawrence River Valleys.

The photographs of anchored rafts of timber were taken at Ottawa on the Ottawa River. Where the other photographs were taken is not known to me.

\section{The Rise and Fall}

\section{of the Square Timber Trade}

The following historical context for the rise and fall of the square timber trade in Ontario is summarized from In Praise of Pine: The Eastern White Pine and Red Pine Timber Harvest from Ontario's Crown Forest. ${ }^{1}$

Pine timber was the major wood product exported from Ontario and Québec in early colonial times. The term "timber" referred initially to wood

\footnotetext{
${ }^{1}$ Aird, Paul L. 1984. In Praise of Pine: The Eastern White Pine and Red Pine Timber Harvest from Ontario's Crown Forest. Information Report PI-X-52, Canadian Forest Service, Chalk River, Ontario.
}

squared on four sides, which was later called "square timber." Timber from the Baltic region of Europe was "diesquare," meaning square throughout its length. For North American timber, a taper of up to $1 \frac{1 / 2}{2}$ inches for 20 feet of white pine and up to 2 inches for 25 feet of red pine, and in proportion for greater lengths, was acceptable.

As Napoleon Bonaparte conquered Europe, he gradually stopped all trade with Britain. By 1808, the Baltic ports were closed to British trade. Although this closure ended two years later, it provided a great impetus to North American trade in square timber with Britain such that by 1828 , the North American colonies were the major supplier of timber to Britain.

The first record of the production of "waney timber" appeared in Canada West (now Ontario) in 1861. Waney timber had four faces, with the corners beveled or left rounded. Although it was still classified as square timber, it was roughly octagonal in shape and much less wasteful than truly square timber. Waney logs usually came from the lower part of the tree, so they were of large dimension and excellent quality, commanding 20 to 30 per cent higher prices. The peak year for Ontario's square timber trade was 1864 , three years prior to Confederation. In that year, about 25 million cubic feet of pine timber was floated down the Ottawa and St. Lawrence Rivers to the Port de Québec for export to Britain. Only square timber was shipped to Britain because it could be tightly packed in a ship's hold. Round sawlogs would roll during storms and break a ship apart.
Shipbuilding activity in the province of Québec also peaked in 1864 because timber-carrying ships formed a large part of the trade. At least 2500 ships were built in Québec between the beginning of British rule in 1763 and the close of the $19^{\text {th }}$ century.

\section{Canada's Wood Merchants} strongly supported Confederation Before Canadian Confederation in 1867, Ontario and Québec were intimately linked by the timber trade. People in these two provinces had learned to cooperate in their trade with Britain and to work jointly in their dealings with the United States. But pior to Confederation, the United States terminated the Reciprocity Treaty that had provided for the free exchange of natural products. This forced Canadian wood merchants formerly involved in the sawlog trade with the United States to seek markets elsewhere. This adjustment in the timber trade did much to strengthen their support to unite the provinces and achieve Confederation.

After 1867, the wood market gradually shifted from the square timber trade with Britain to the sawlog trade with the United States. From 1879, Britain accepted lumber as well and the square timber trade was doomed.

Paul Leet Aird

Professor Emeritus, Faculty of Forestry, University of Toronto, Ontario. Email: paul.aird@utoronto.ca 


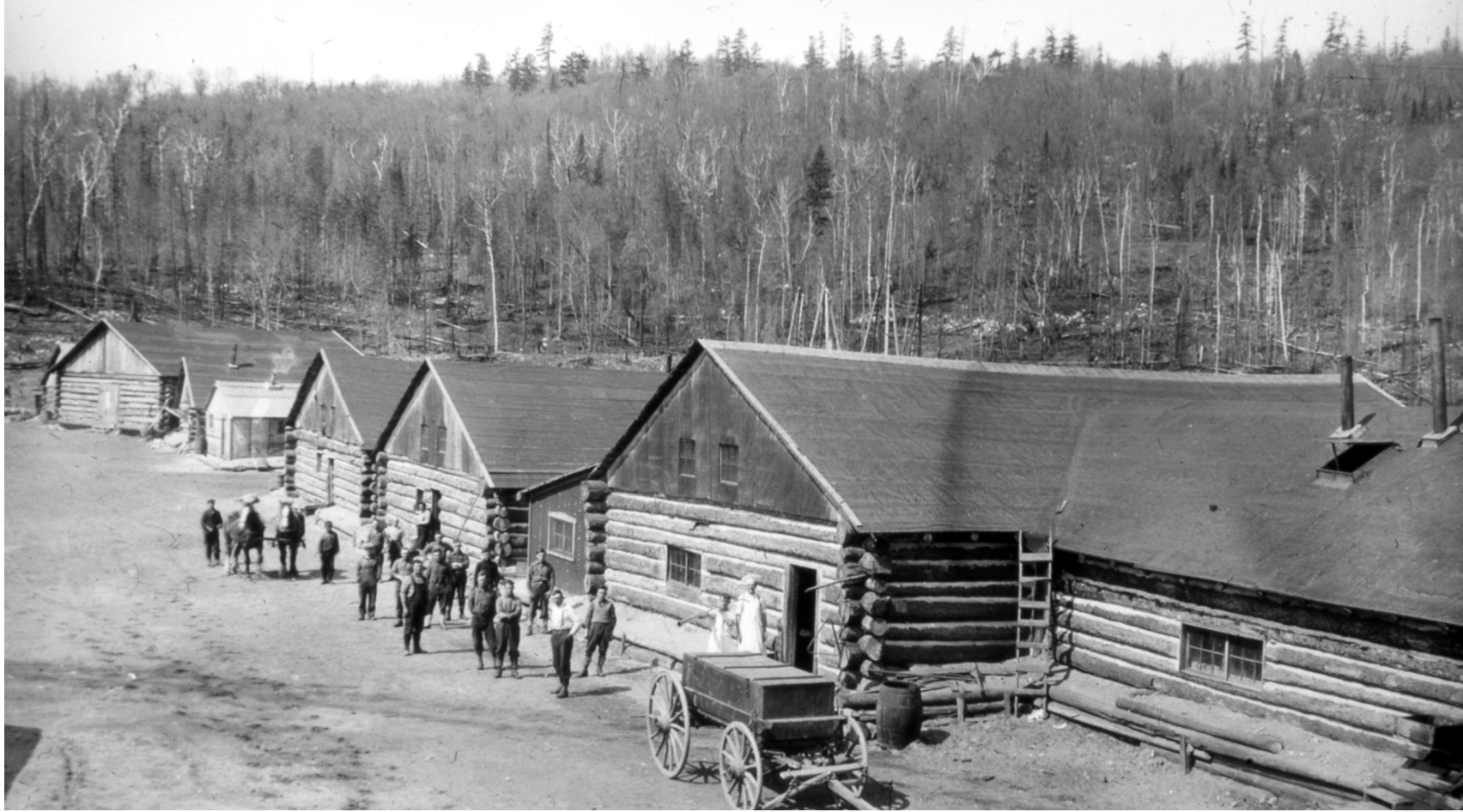

Logging camps were built of hand-hewn wood, first with over-lapping boards on the roof and later with flat boards covered with tarpaper. A typical building arrangement shows the cook and cookee (cook's helper) standing in front of the cookhouse and eating area; an attached building where the cook lives; two bunkhouses; camp clerk's office and home; blacksmith shop; and a horse stable with space to store horse feed. Every camp hired a "chickadee" to maintain the snow roads by removing horse droppings, and adding snow and water to make the roads smoother.

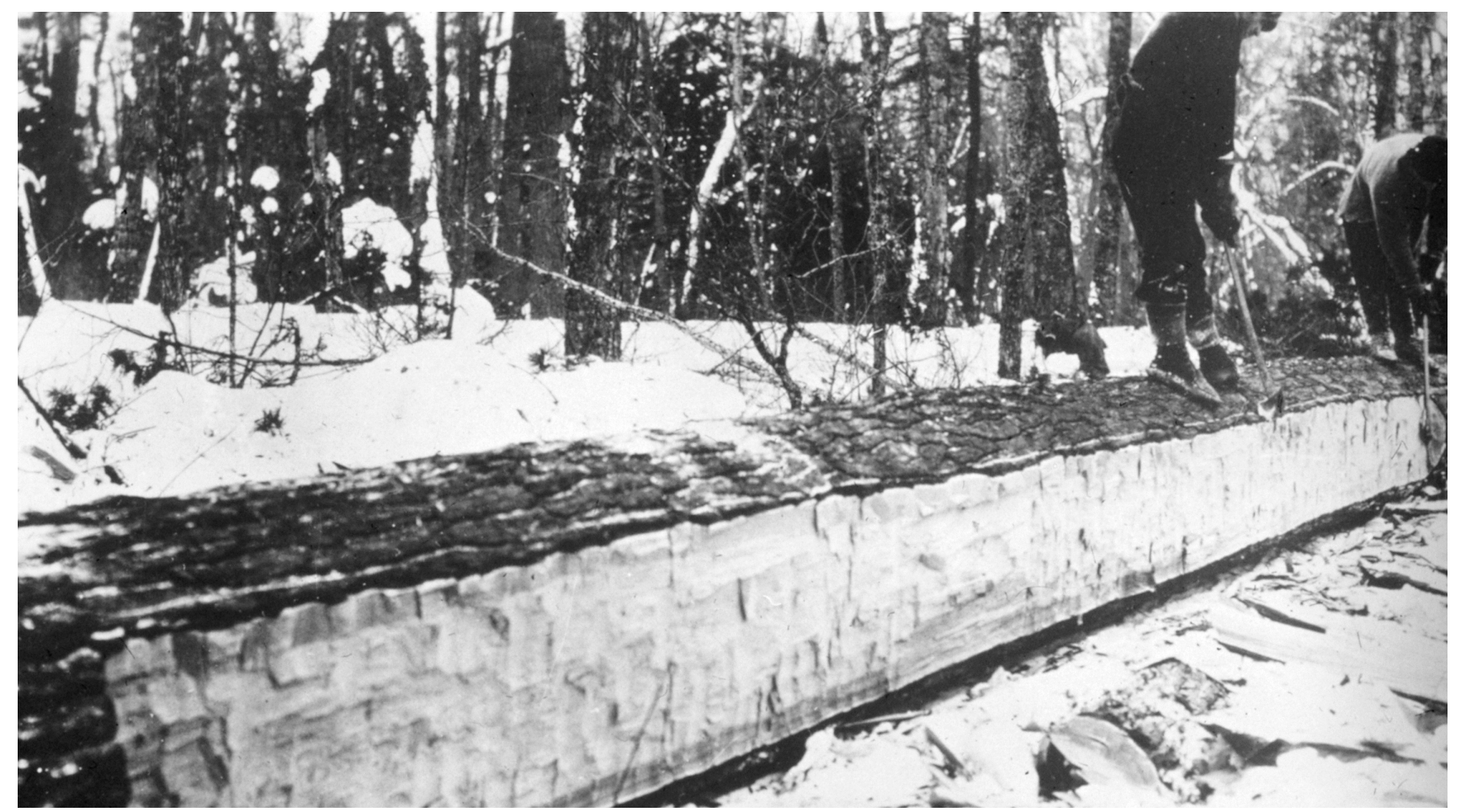

When beginning to square a 20 -foot log, a straight line was carved into the bark to mark the final cut. In this case, the scored line has filled with snow. 


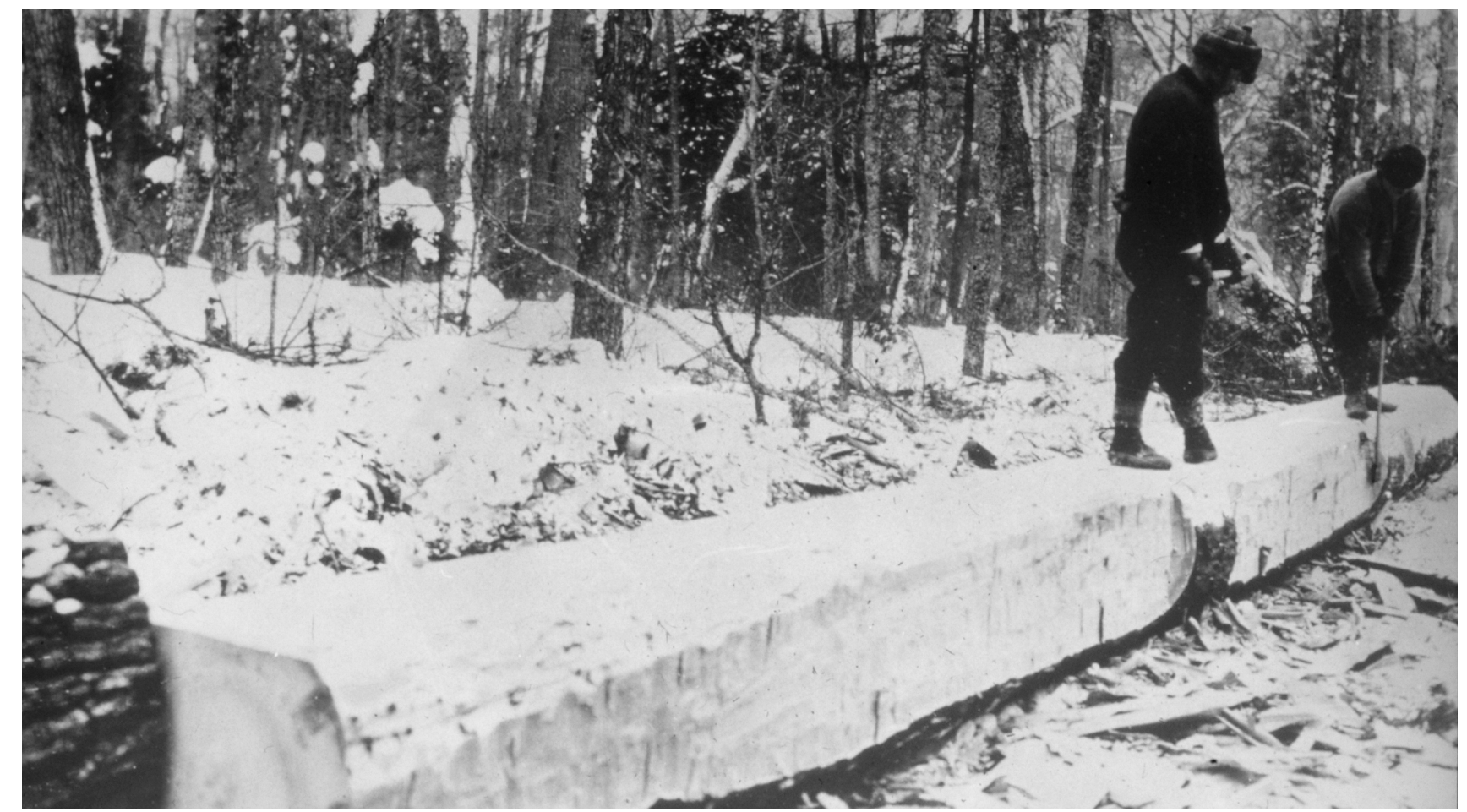

Heavy axes were used to hew grooves across the log. Each section of wood left between two grooves was then split off.

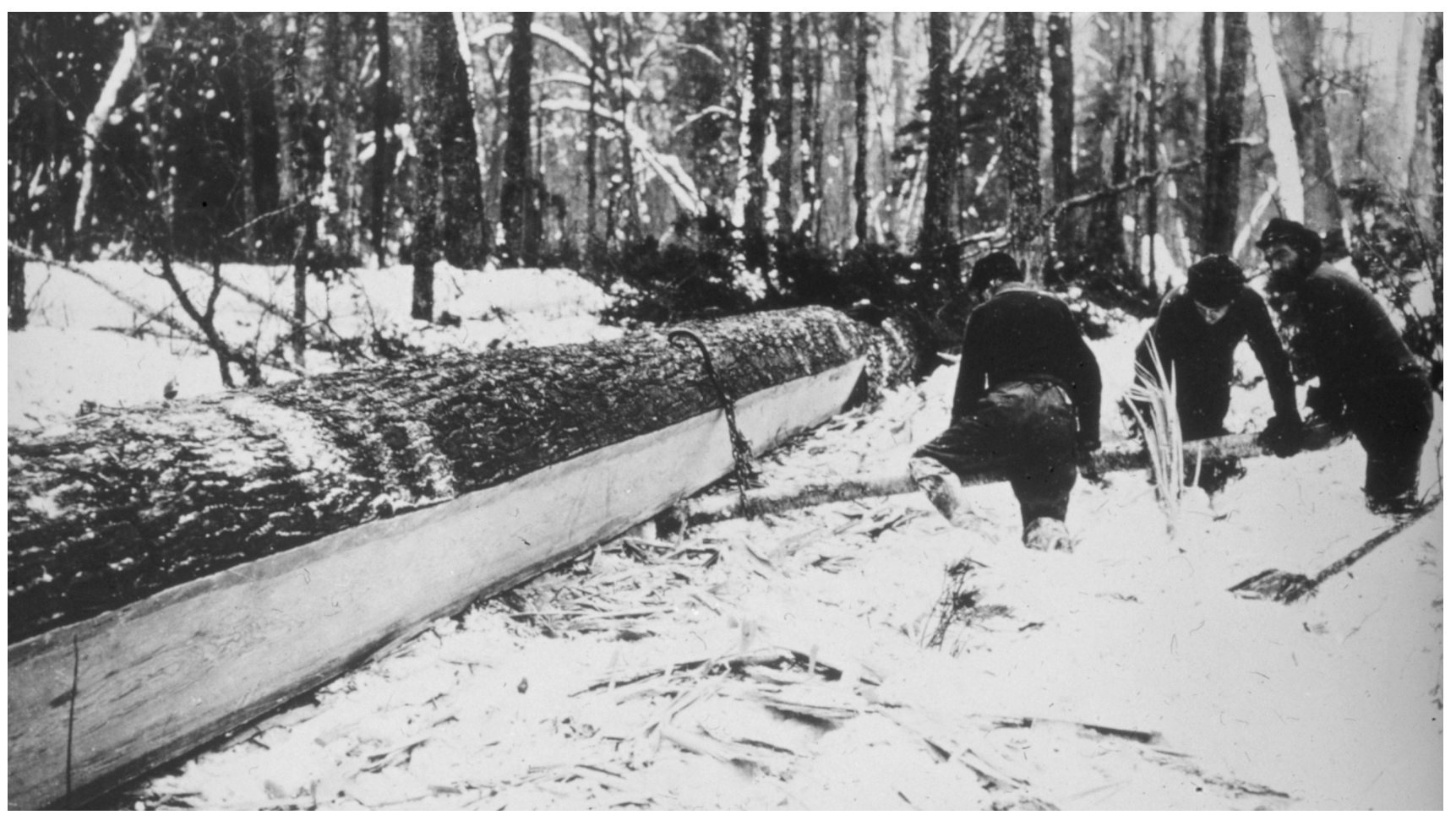

Normally, a crew of three men would work together in felling, bucking, squaring the log and skidding the squared timber to the landing. 


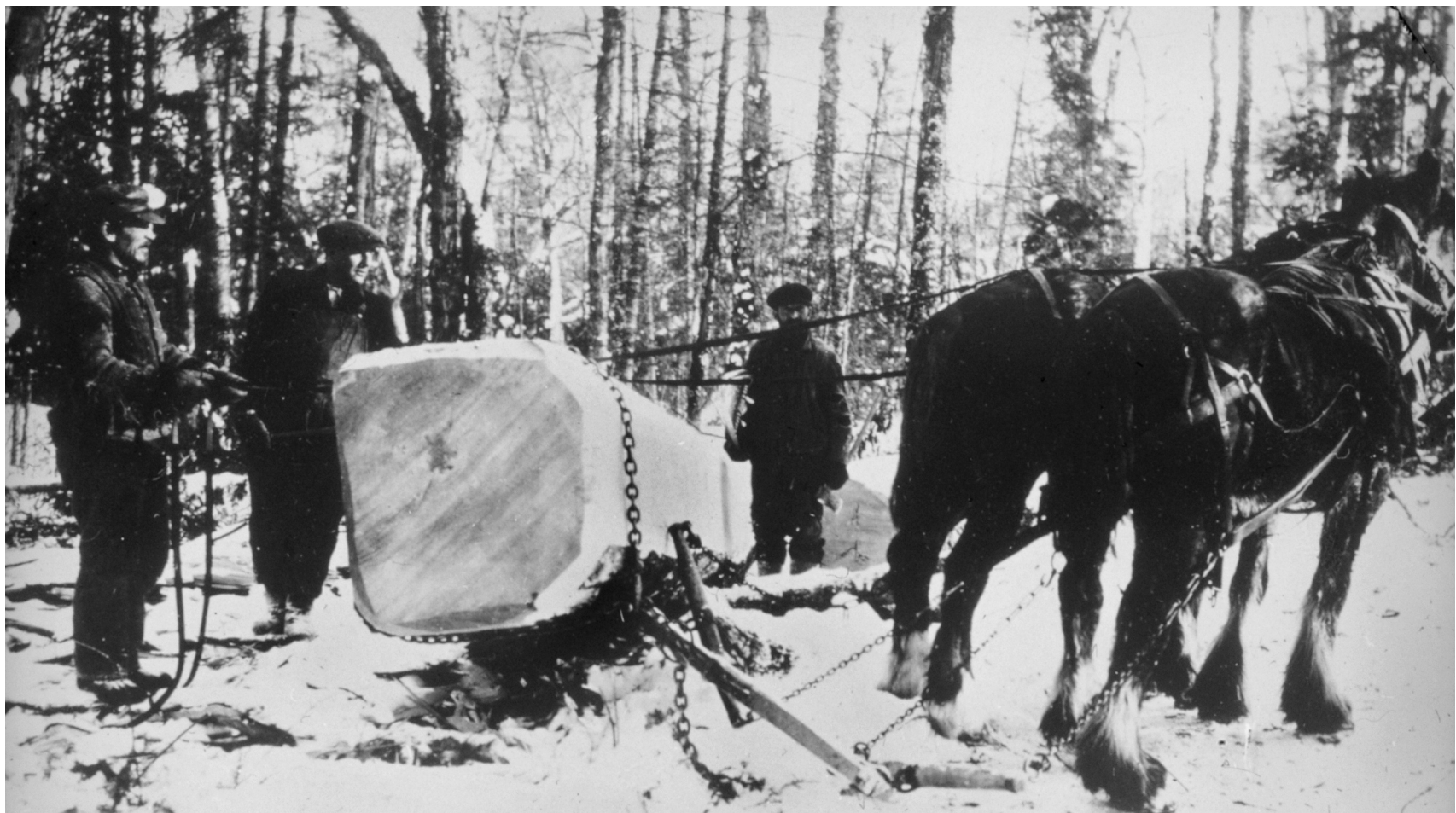

A team of horses about to skid a waney log to the landing. Note how the end of the log has been shaped so that it will slide easily over rough ground.

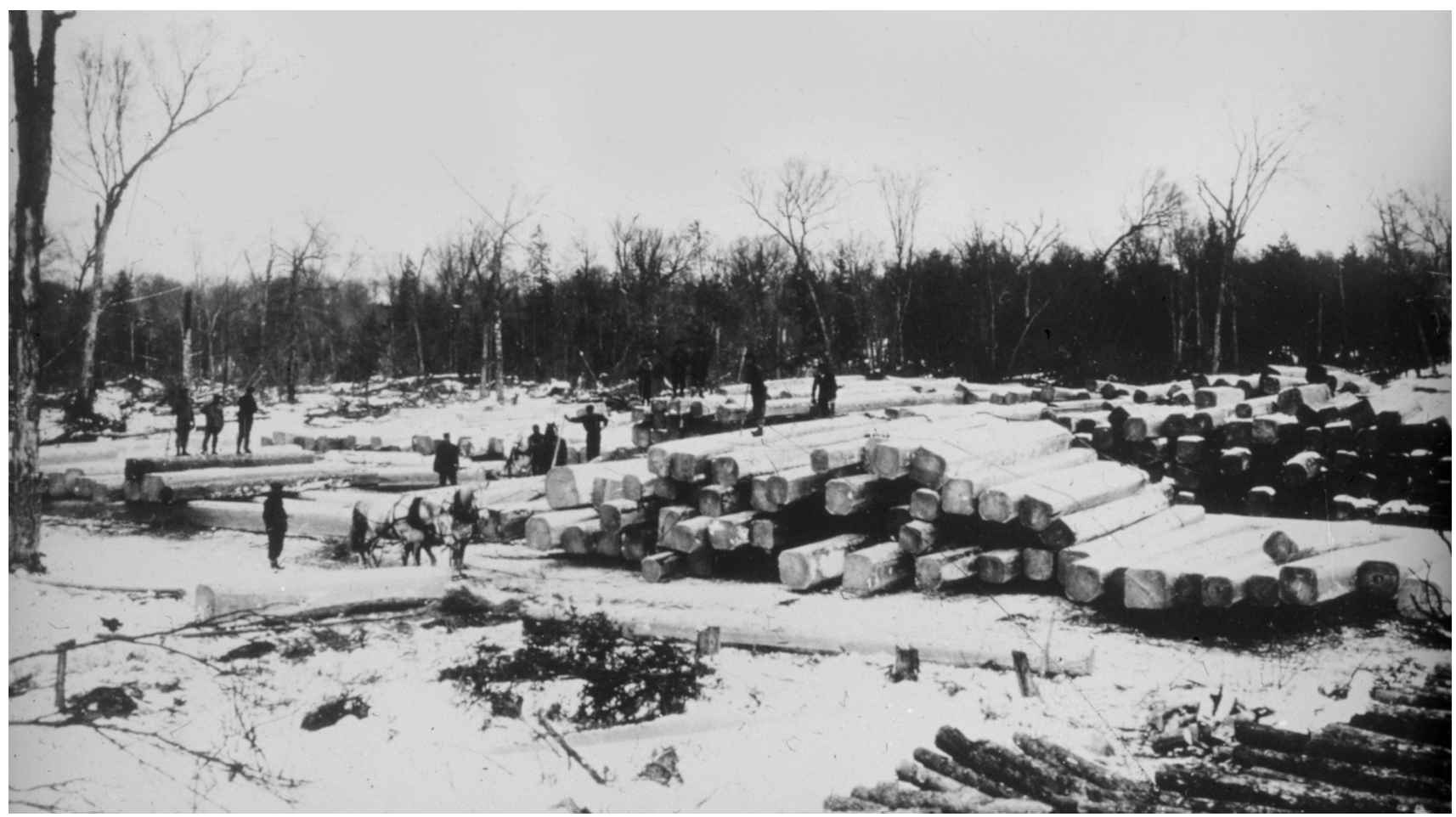

A landing where the individual pieces of square timber were skidded and arranged in piles. 


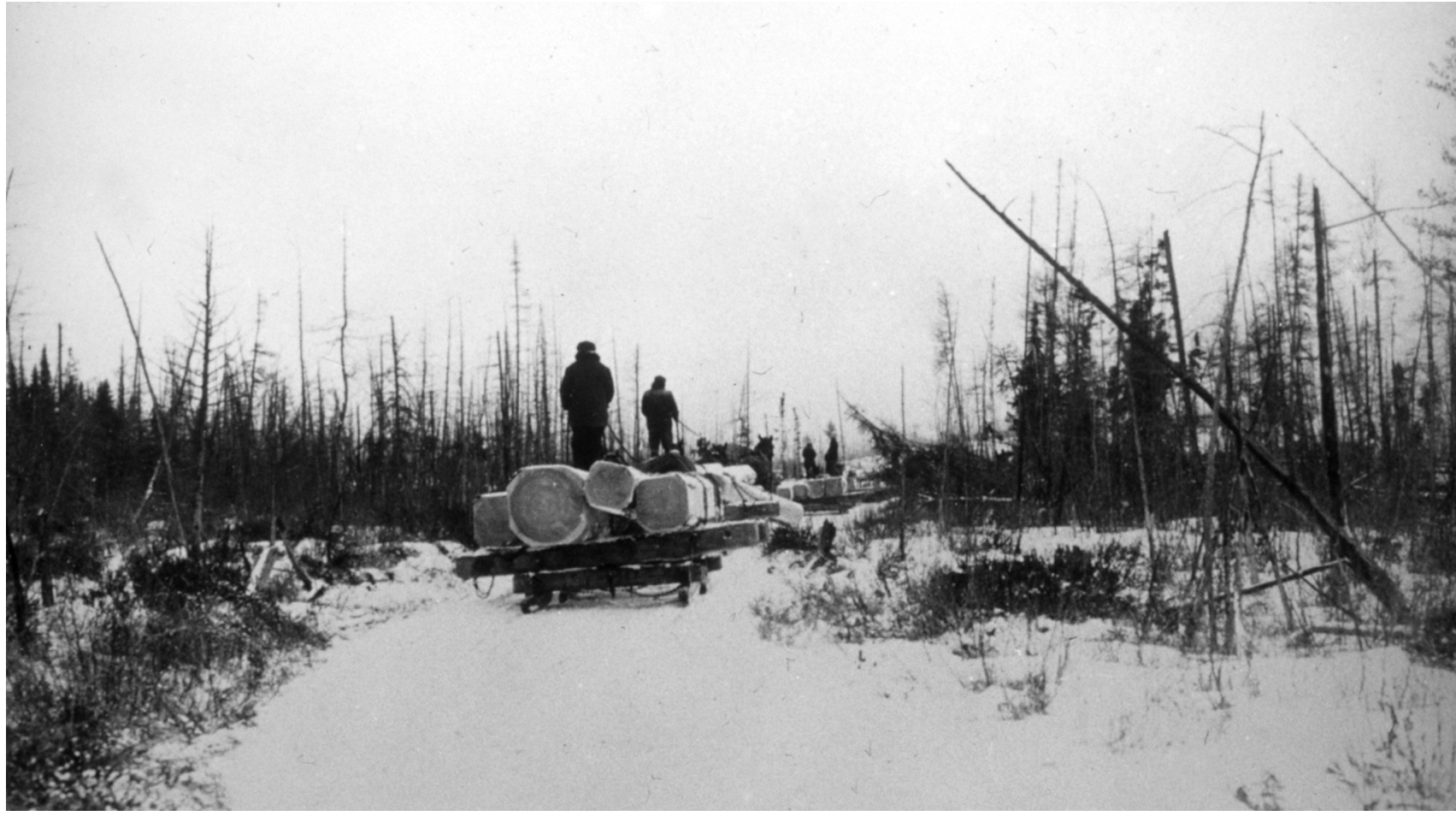

The square timber was moved by sleigh from the landing to be dumped on the ice of a nearby lake or stream when the ice was thick enough to bear heavy loads. Sleighs were built from local wood, and from iron shaped by the blacksmith into sleigh runners.

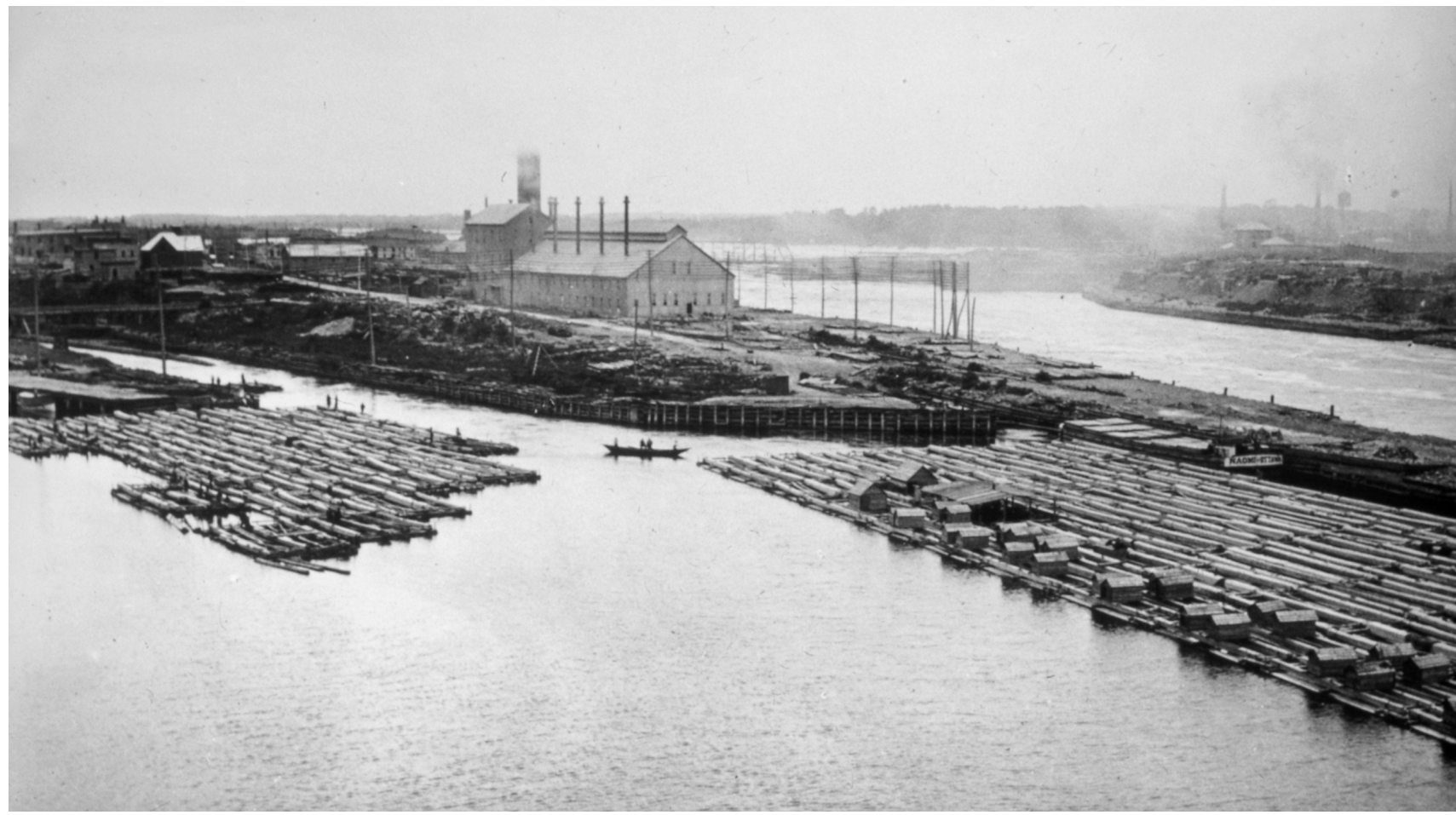

After the ice had melted in spring, the square timbers were floated downstream to a major river such as the Ottawa and Saint Lawrence Rivers, where they would be formed into rafts for the journey to the Port de Québec. These rafts are on the south side of Victoria Island, Ottawa, Ontario. Each raft consisted of up to 100 cribs pinned together with wooden pins. They had first been moored above Chaudière Falls, disassembled into sections containing several cribs, floated down a narrow slide that carried the cribs safely below the water fall, and reassembled to float down the next stretch of open water. 


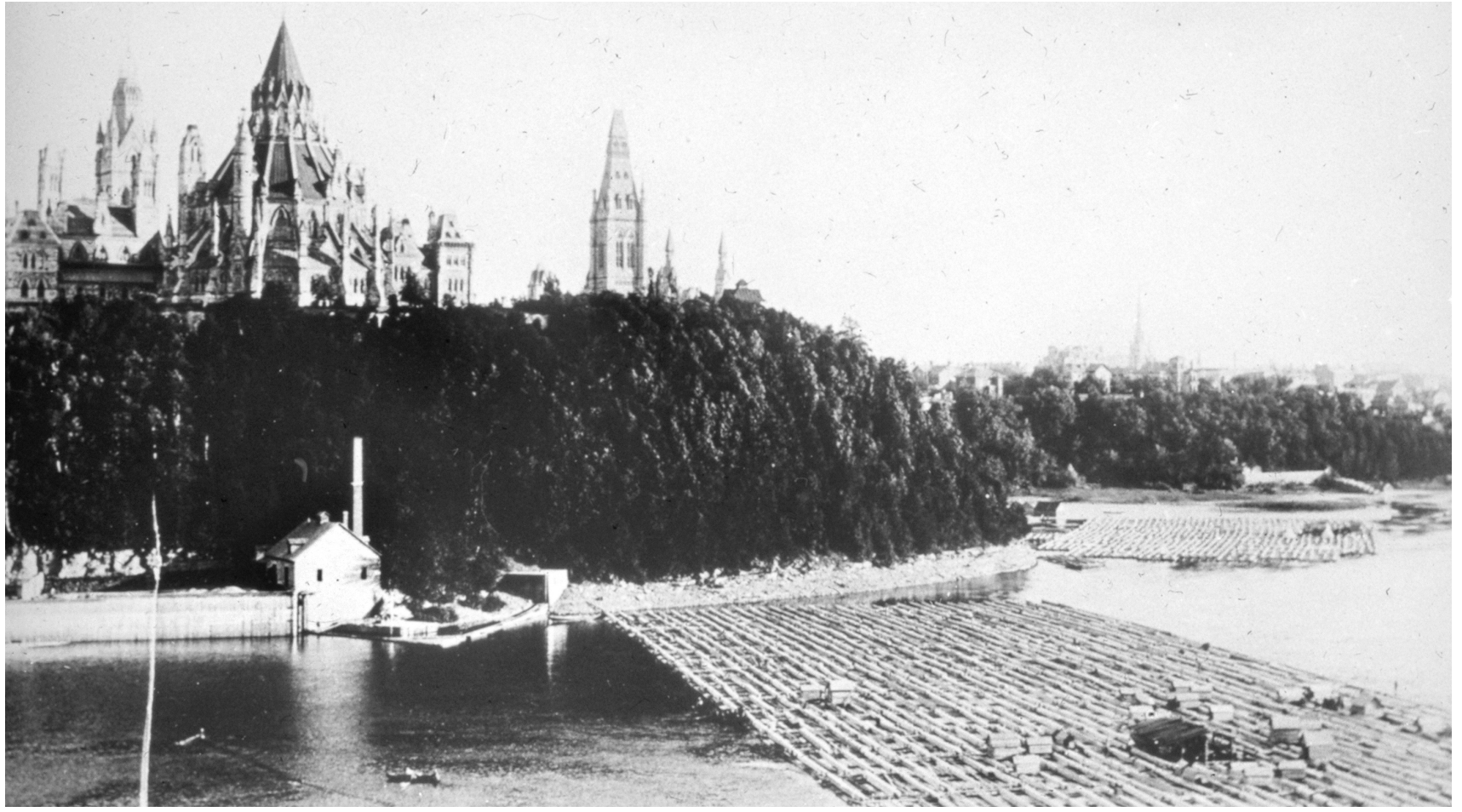

Two timber rafts are anchored below Parliament Hill. Select hardwood logs and pine planks were often carried on top of the rafts. The raft in the foreground contains about 70 cribs. The dark structure is the camboose, a roofed structure that covered an open fire for cooking and eating.

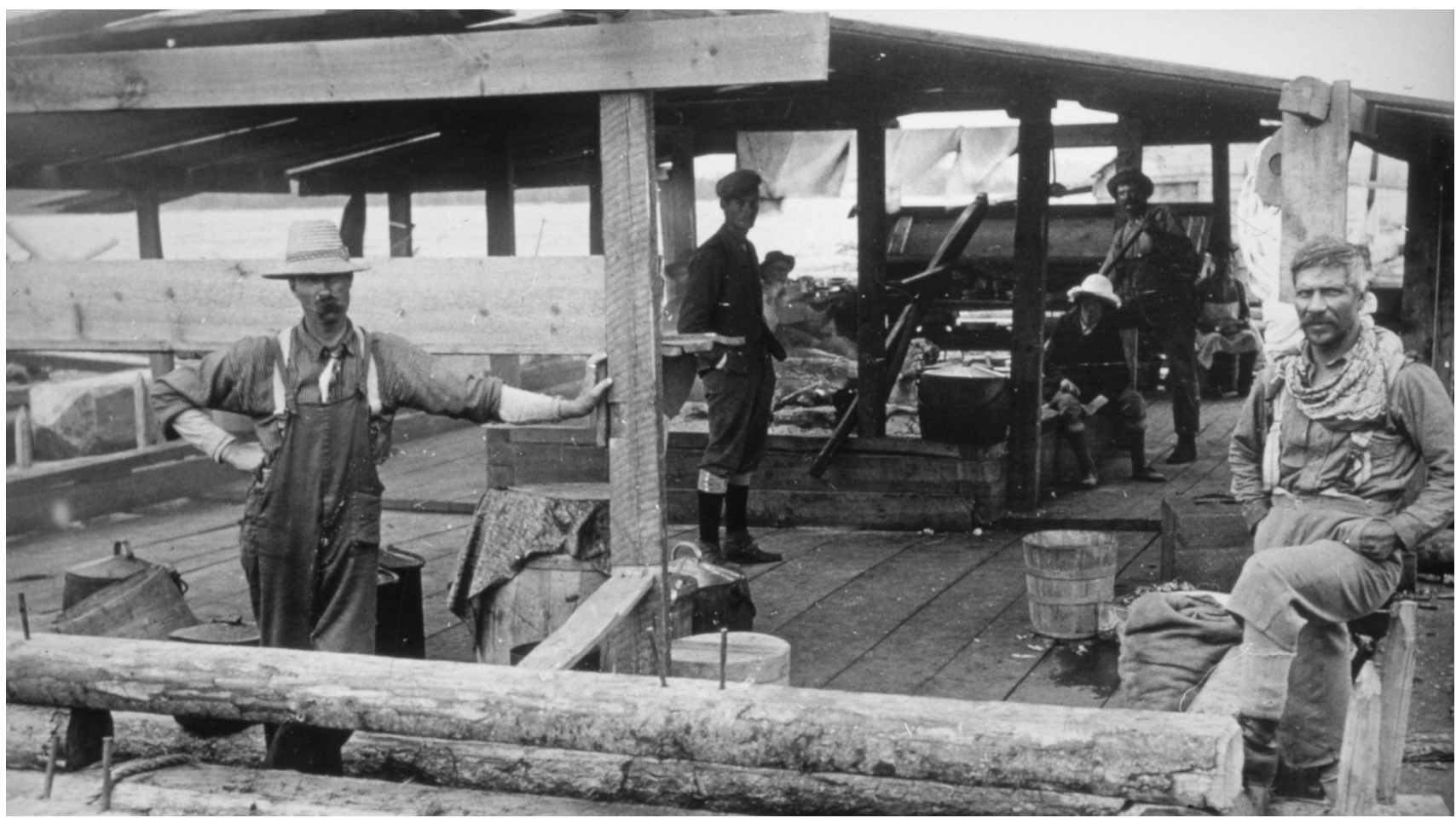

A close view of a camboose. The raised structure in the middle is filled with sand to contain the open fire. Food was cooked by hanging pots over the fire or by burying them in the hot sand. 


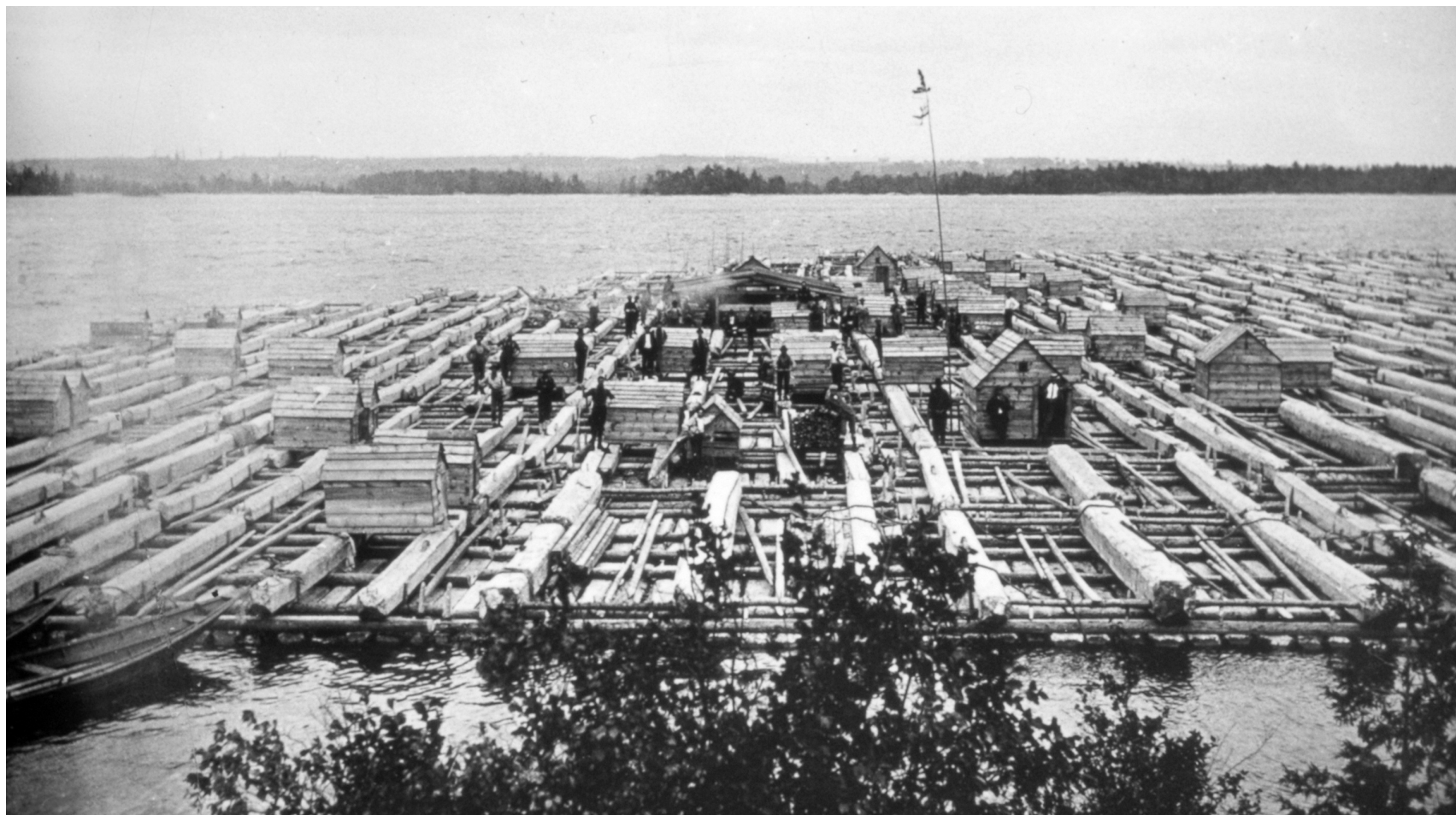

A ceremonial coniferous tree was raised on each raft when it was fully assembled to signify respect for nature's ways, pride of team accomplishment, and to signal that the raft was moving on. It would also serve as a mast with rope and pulley to raise a sail in a favourable wind, and as a lightning rod. About 30 men would live and work on this raft for several months. Each raftsman had built his own house to sleep in, and would sell the house when the raft reached its destination. The raft floated downstream with the current, sometimes helped with 30-foot-long oars (sweeps) to keep it in the channel, or with a large sheet of canvas raised as a sail. When the raft reached the next stretch of dangerous rapids, it was moored to shore, disassembled, floated in sections down the rapids and reassembled with the ceremonial coniferous tree on top.

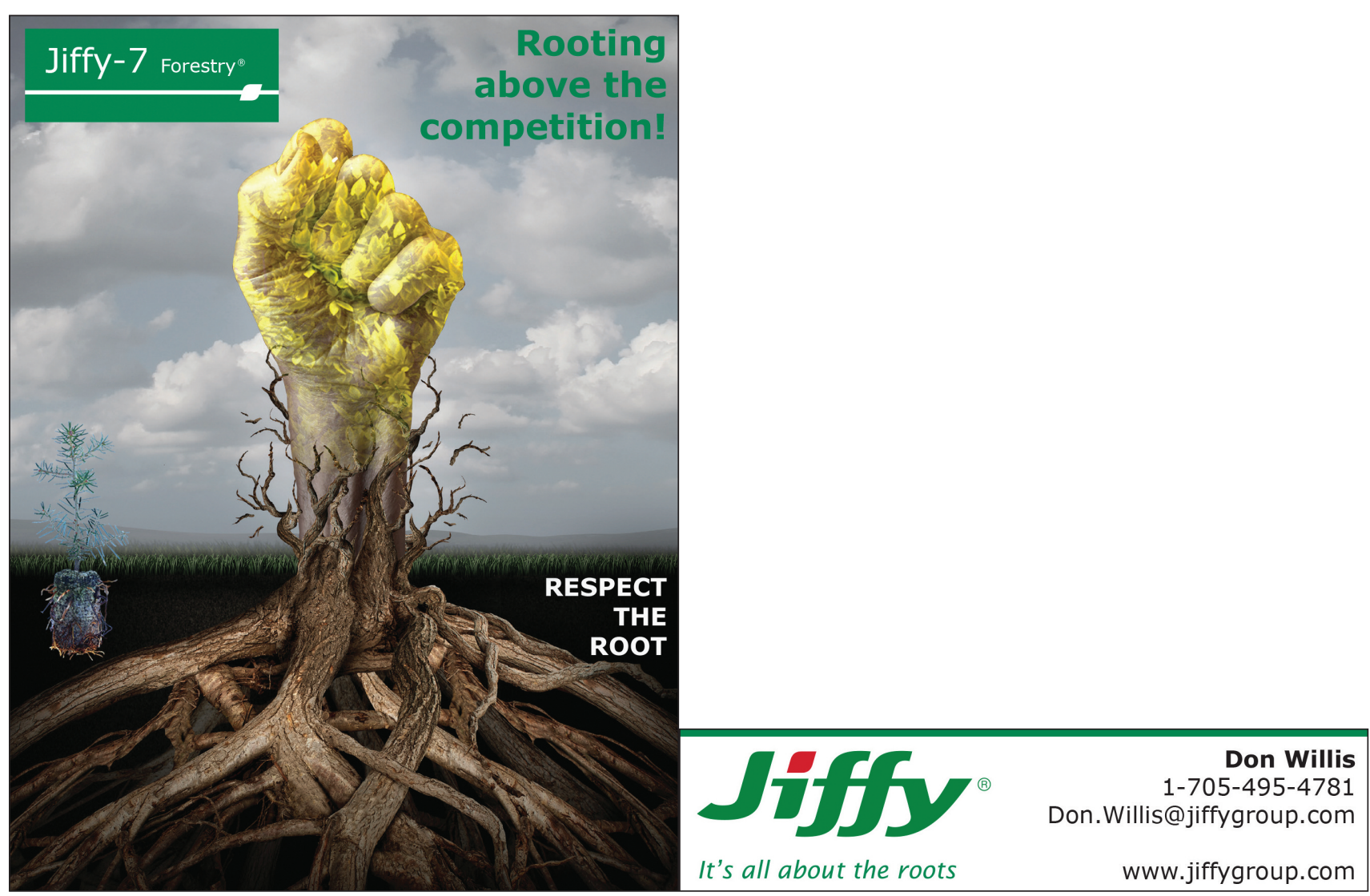

